\title{
The Relationship Between Teacher Candidates' Self-Efficacy and Attitudes of Sports History
}

\author{
Abdullah Yavuz Akınc1 ${ }^{1}$ \\ ${ }^{1}$ Faculty of Sports Science, Süleyman Demirel University, Isparta, Turkey \\ Correspondence: Abdullah Yavuz Akınc1, Faculty of Sports Science, Süleyman Demirel University, Isparta, \\ Turkey. E-mail: abdullahakinci@sdu.edu.tr
}

Received: March 12, 2020

Accepted: April 23, $2020 \quad$ Online Published: June 21, 2020

doi:10.5539/ies.v13n7p105

URL: https://doi.org/10.5539/ies.v13n7p105

\begin{abstract}
The objective of the present study is to analyze the relationship between physical education and sports teacher candidates' academic self-efficacy and attitudes towards the course of sports history.

The population of the present study consists of 240 junior and senior teacher candidates studying at School of Physical Education and Sports at Yozgat Bozok University and Faculty of Sports Sciences at Erciyes University and Mehmet Akif Ersoy University. The sample group consists of 138 participants randomly selected from the population.

A Personal Information Form developed by the researcher, academic self-efficacy scale developed by Jerusalem and Schwarzer (1981) and adapted to Turkish context by Yılmaz, Gürçay, and Ekici (2007), and the attitude scale towards the course of sports history developed by Y1lmaz, Namli, and Kan (2013) were used for data collection.

The data obtained in the study were analyzed using a personal computer. Numbers, percentages, mean values and standard deviations were used as descriptive statistical methods in the data analysis. Pearson correlation analysis was applied to the continuous variables of the study.

As a result, a positive correlation was found between physical education teacher candidates' self-efficacy and attitudes towards the course of sports history. It can be suggested that this tendency stems from teacher candidates' academic development during their education as a university student, which is a transition to a professional life, and their belief in the importance of transferring their academic development to younger generations during their professional career.
\end{abstract}

Keywords: academic self-efficacy, attitude, physical education and sports, sports history

\section{Introduction}

In addition to leading important innovations in the history of humanity from the past to the present (Karakuş \& Köse, 2018), technological developments also continuously encourage people to aim for a higher degree of perfection (Karakuş, 2012). The potential of academically successful citizens bears utmost importance in the development and excellence of societies. It is acknowledged that education plays a crucial role in raising individuals who can think in all areas of life, process information, make their own decisions and try to reach perfection as a potentially successful individual.

In this respect, the concept of academic self-efficacy can be defined as an individual's perception that $\mathrm{s} / \mathrm{he}$ can perform a given academic task and responsibility at a certain level of success (Donmuş, Akpınar, \& Eroğlu, 2017). According to another definition, academic self-efficacy is related to an individual's motivation, academic choices and success (Pajares, 1996).

Attitude as a factor affecting academic success (Kan \& Akbaş, 2005) is used to express an individual's tendency to react to any phenomenon or object (Demirel \& Ün, 1987; Gözler \& Taşç1, 2015). Another definition approaches attitude as a neural and mental state resulting from direct or indirect phenomena organized by previous experiences and readiness, which directly or indirectly influence an individual's reactions to all similar events and topics (Shapiro, 1999).

Nowadays, expanding its sphere of influence, sports have started to function as a powerful educational tool in solving social problems in order to respond to individuals' different expectations. It is a tool that contributes 
positively to individuals' entire lives and enables them to develop. It has been scientifically proven that a conscious and regular experience of sports played an important role in preserving an individual's health and success and boosting their personal mood, regardless of age (Yalçınkaya, Saracaloğlu, \& Varol, 1993).

Yıldırım and Bayrak (2019) stated that students increased their quality of life and socialization through participation in sports based physical activities, which had a positive effect on their overall academic success. Therefore, it is evident that training effective physical education and sports teachers with professional and personal competencies is important in raising healthy and successful generations.

Because teachers occupy an important position in the education system, they should be good observers and guides in line with the goals of the teaching-learning processes in order to offer efficiency in education and develop positive attitudes.

An effective teacher must possess two basic qualities: personal and professional. While expected personal qualities include tolerance, patience, open-mindedness, affection, understanding and humor, expectation of high success from the student, and encouragement and support for the student, professional qualities can be listed as general culture, subject area knowledge, professional knowledge and teaching skills (Erden, 1998). It is considered that the level of knowledge in sports history, which is among professional qualities for a physical education and sports teacher, is very important.

In general terms, history emerges as an academic discipline of educational sciences with an educational (to gain knowledge, skills and attitudes of historical content determined by history teaching programs) and academic research (the determination of scientific problems and barriers encountered in the education of history, solutions to these problems and offering concrete suggestions) aspect (Demircioğlu, 2014).

The history of sports, which is one of the fundamental courses at the departments of sports, is thought to be very significant in terms of informing younger generations about successful and inspiring athletes in the history of sports, and the history of sports activities from the past to the present.

The literature review demonstrates that there are studies focusing on academic/self-efficacy (Turan, Karaoğlu, Kaynak, \& Pepe 2016; Saracaloğlu et al., 2017; Izgar \& Dilmaç, 2008; Caba \& Pekel, 2017), attitude (Pepe et al., 2011; Turan, Usuflu, Koç, Karaoğlu, \& Ulucan, 2018; Dalbudak, Gürkan, Yigit, Kargun, Hazar, \& Dorak, 2016; Dalbudak \& Yiğit, 2019; Alp \& Süngü, 2016; Kumartaşlı, 2010; Yıldırım, Araç-Ilgar, \& Uslu, 2018) and sports history (Yılmaz et al., 2013; Dönmez, 1998; Turkay \& Aydın, 2017; Abe, 1991) in the existing literature. However, no studies investigating physical education and sports teacher candidates' attitudes towards academic self-efficacy and the course of sports history were found. In the light of this, the present study aims to analyze the relationship between physical education and sports teacher candidates' academic self-efficacy and attitudes towards the course of sports history.

\section{Methods}

\subsection{Model of the Study}

The present study uses descriptive and relational survey model. It can be defined as "a research model aiming to determine the presence and/or the degree of co-variation between two and more variables" (Karasar, 2007).

\subsection{Creating Volunteer Groups}

The population of the present study consists of 240 junior and senior teacher candidates studying at School of Physical Education and Sports at Yozgat Bozok University and Faculty of Sports Sciences at Erciyes University and Mehmet Akif Ersoy University. The sample group consists of 138 participants randomly selected from the population (Çıngı, 1994). 
Table 1. Participants' demographic features

\begin{tabular}{|c|c|c|c|}
\hline & Variables & $\mathrm{N}$ & $\%$ \\
\hline \multirow{3}{*}{ Gender } & Male & 84 & 60.9 \\
\hline & Female & 54 & 39.1 \\
\hline & Total & 138 & 100 \\
\hline \multirow{3}{*}{ Age } & $18-21$ & 91 & 65.9 \\
\hline & $22+$ & 47 & 34.1 \\
\hline & Total & 138 & 100 \\
\hline \multirow{4}{*}{ University } & MAKÜ & 44 & 31.9 \\
\hline & Erciyes & 37 & 26.8 \\
\hline & Bozok & 57 & 41.3 \\
\hline & Total & 138 & 100 \\
\hline \multirow{4}{*}{ Grade Point Average } & $1.25-1.99$ (Low) & 8 & 5.8 \\
\hline & $2.00-2.99$ (Mid) & 74 & 53.6 \\
\hline & $3.00-4.00$ (High) & 56 & 40.6 \\
\hline & Total & 138 & 100 \\
\hline \multirow{4}{*}{ Accommodation } & Hostel & 18 & 13.0 \\
\hline & Family & 85 & 61.6 \\
\hline & Housemates & 35 & 25.4 \\
\hline & Total & 138 & 100 \\
\hline \multirow{3}{*}{ Weekly Work Time } & $1-10$ & 91 & 65.9 \\
\hline & $11+$ & 47 & 34.1 \\
\hline & Total & 138 & 100 \\
\hline
\end{tabular}

When Table 1 is analyzed, it can be observed that $60.9 \%$ of the participants is male, while $39.1 \%$ of them is female. $65.9 \%$ of the participants is aged between 18 and 21 , whereas $34.1 \%$ of them is aged 22 years old and over. $31.9 \%$ of the participants study at Mehmet Akif Ersoy University, 26.8\% of the participants study at Erciyes University, and $41.3 \%$ of the participants study at Bozok University. Grade point average of the participants is $5.8 \%$ low, $53.6 \%$ medium, and $40.6 \%$ high. $13 \%$ of the participants live in hostel, $61.6 \%$ of them live by their families, and $25.4 \%$ of them live with a housemate. According to their weekly work time data, $65.9 \%$ of the participants work for 1 to 10 hours, while $34.1 \%$ of them work for 11 hours and above.

\subsection{Data Collection Techniques}

In order to collect data in the present study, a personal information form prepared by the researcher, academic self-efficacy and attitude scales for the course of sports history were used.

\subsection{Personal Information Form}

It contains six questions in order to obtain the participants' gender, age, the university which they attend, academic grade point average, accommodation and weekly work time.

\subsection{Academic Self-Efficacy Scale}

The scale developed by Jerusalem and Schwarzer (1981) (Academic Self-Efficacy Scale) measures students' levels of academic self-efficacy through 7 items in one dimension. The items were designed using a 4-point Likert type scale. The original scale was developed after it had been applied to medical school students, and the Cronbach Alpha value of the scale was calculated as 0.87 .

The Turkish adaptation of the scale was carried out by Yilmaz et al. (2007). The Turkish version of the scale was applied to 672 prospective university students from different academic fields. The findings of the analysis indicated that one-dimensional and 7-item structure of the original scale was preserved in Turkish scale, too. Cronbach Alpha reliability value of the scale was calculated as .79. Thus, academic self-efficacy scale can be considered as a valid and reliable scale to determine university students' self-efficacy related to academic learning in Turkey.

\subsection{Attitude Scale for Sports History Course}

The scale developed by Yilmaz et al. (2013) to determine the attitudes of the students studying at School of Physical Education and Sports towards the course of sports history consists of 20 items. The items of the 5-point Likert type scale are scored as (1) 'I strongly disagree', (2) 'I disagree', (3) 'I am indecisive', (4) 'I agree' and 
(5) I strongly agree. 12 of these items are positive, whereas 8 of them are negative. The first of the three factors in the scale is defined as "Feelings for the lesson", the second is "Achievements in the Course of Sports History Course", and the third is the "Activity Dimension". The first, second and third sub-factors consist of 13, 4 and 3 items, respectively. To test the reliability and homogeneity of the scale, Cronbach Alpha reliability coefficient was examined, which was found to be 0.91 . A calculated reliability coefficient of 0.70 and higher is generally accepted as sufficient for the reliability of the test scores.

\subsection{Statistical Analysis}

Shapiro-Wilk test is only one of the methods used to study the normality of the statistical data. According to the statistical data obtained from the present study, skewness and kurtosis distributions are given in Table 2 .

Table 2. Skewness-Flatness and Shapiro-Wilk test significance level results of participants' scale scores

\begin{tabular}{lccc}
\hline & $\mathrm{N}$ & Skewness & Kurtosis \\
\hline Academic Self-Efficacy & 138 & -.771 & 1.120 \\
Emotions for the Course of Sports History & 138 & -1.085 & .896 \\
Achievements in the Course of Sports History & 138 & -.736 & .028 \\
Activities in the Course of Sports History & 138 & -.121 & -.647 \\
Total Attitude Towards the Course of Sports History & 138 & -.726 & .158 \\
\hline
\end{tabular}

When Shapiro-Wilk Test results are analyzed, it can be observed that participants' attitude scores towards academic self-efficacy and the course of sports history displayed a significant level of deviation from normality (Table 2). Normal distribution curves demonstrate that there were no excessive deviations from normality. In the existing literature, while George and Mallery (2016) argue that the values of skewness and kurtosis are ideally acceptable between \pm 1 , Demir, Saatçioğlu, and İmrol (2016) argue that these values must be within a range of \pm 2 for normality.

Under these circumstances, it was decided to use parametric statistical analysis tests. The data obtained from the present study were analyzed using a personal computer. Numbers, percentages, mean values and standard deviations were used as descriptive statistical methods in the data analysis. Pearson correlation analysis was applied to the continuous variables of the present study.

\section{Findings}

Table 3. Descriptive statistics of the scores obtained from the scales

\begin{tabular}{lcccc}
\hline & $\mathrm{N}$ & $\mathrm{Min}$ & $\mathrm{Max}$ & $\mathrm{X} \pm \mathrm{Sd}$ \\
\hline Academic Self-Efficacy & 138 & 11.00 & 35.00 & $26.275 \pm 4.410$ \\
Feelings for the Course of Sports History & 138 & 17.00 & 65.00 & $50.355 \pm 10.480$ \\
Achievements in the Course of Sports History & 138 & 4.00 & 20.00 & $15.558 \pm 3.771$ \\
Activities in the Course of Sports History & 138 & 3.00 & 15.00 & $9.188 \pm 3.365$ \\
Total Attitude Towards the Course of Sports History & 138 & 33.00 & 100.00 & $75.101 \pm 13.738$ \\
\hline
\end{tabular}

It can be understood from Table 3 that the academic self-efficacy of the physical education and sports teacher candidates who participated in the study was $26.275 \pm 4.410$. It was found that participants' mean scores were $50.355 \pm 10.480$ in the sub-dimension of feelings for the course of sports history, $15.558 \pm 3.771$ for the sub-dimension of achievements, $9.188 \pm 3.365$ for the sub-dimension of activities, and their total scores for the attitude towards the course of sports history were calculated as $75.101 \pm 13.738$. 
Table 4. The relationship between participants' academic self-efficacy and attitudes towards the course of sports history

\begin{tabular}{|c|c|c|c|c|c|c|}
\hline & & 1. & 2 & 3 & 4 & 5 \\
\hline \multirow{3}{*}{ 1. Academic Self-Efficacy } & $\mathrm{r}$ & 1 & & & & \\
\hline & $\mathrm{p}$ & & & & & \\
\hline & $\mathrm{n}$ & 138 & & & & \\
\hline \multirow{3}{*}{ 2. Feelings for the Course of Sports History } & $\mathrm{r}$ & .025 & 1 & & & \\
\hline & $\mathrm{p}$ & .771 & & & & \\
\hline & $\mathrm{n}$ & 138 & 138 & & & \\
\hline \multirow{3}{*}{ 3. Achievements in the Course of Sports History } & $\mathrm{r}$ & .417 & .386 & 1. & & \\
\hline & $\mathrm{p}$ & .000 & .000 & & & \\
\hline & $\mathrm{n}$ & 138 & 138 & 138 & & \\
\hline \multirow{3}{*}{ 4. Activities in the Course of Sports History } & $\mathrm{r}$ & .316 & .120 & .565 & 1 & \\
\hline & $\mathrm{p}$ & .000 & .159 & .000 & & \\
\hline & $\mathrm{n}$ & 138 & 138 & 138 & 138 & \\
\hline \multirow{3}{*}{ 5. Total Attitude Towards the Course of Sports History } & $\mathrm{r}$ & .211 & .898 & .707 & .492 & 1 \\
\hline & $\mathrm{p}$ & .013 & .000 & .000 & .000 & \\
\hline & $\mathrm{n}$ & 138 & 138 & 138 & 138 & 138 \\
\hline
\end{tabular}

When Table 4 is analyzed, a low positive correlation was found between physical education and sports teacher candidates' academic self-efficacy and attitudes towards the course of sports history in the sub-dimension of achievements $(\mathrm{r}=.417, \mathrm{p}=.000)$ and activities $(\mathrm{r}=.316, \mathrm{p}=.000)$, and their total score of attitude towards the course of sports history $(\mathrm{r}=.211, \mathrm{p}=.013)$.

\section{Discussion and Conclusion}

Today, university education is a very critical phase that affects individuals throughout their lives in terms of academic success and transferring their achievements to later stages of their lives. At this point, it must be underlined that prospective teachers' knowledge and achievements will positively influence their professional achievements and that it is of vital importance to transfer this knowledge to younger generations in order to raise academically successful generations.

It was found out in the present study that that the physical education and sports teacher candidates' academic self-efficacy, mean scores in the sub-dimension of emotions, achievements and activities, and total scores of attitudes towards the course of sports history were above average (Table 3).

Ünlü and Erbaş (2018) reported in a study on physical education teacher candidates that participants' academic self-efficacy levels were moderate. Similarly, Şeker (2017) stated in another study on music teacher candidates that academic self-efficacy levels of prospective teachers studying in the department of music education were moderate. On the other hand, there were also studies which reported that physical education teacher candidates' academic self-efficacy levels were higher than the average (Alemdağ, Öncü, \& Yılmaz, 2014), and physical education and sports students' academic self-efficacy levels were high (Ünlü \& Kalemoğlu, 2011). The differences between the findings of the present study and those of the above-mentioned studies in the existing literature can be attributed to educational differences which result from different course features in sampling groups' curricula, physical and geographical differences in universities at which the sample groups are studying and the provinces in which they live.

No studies on the attitudes towards the course of sports history have so far been conducted in the existing literature. In the present study, it is argued that the fact that physical education and sports teacher candidates' attitudes towards the course of sports history is above average can be associated with their current active or sedentary sports life experiences in line with ongoing changes and developments in the related sports branches.

In the present study, a low level of positive correlation was found between participants' academic self-efficacy and the sub-dimension of achievements and activities, and their total scores of attitude towards the course of sports history (Table 4).

It can be seen in academic studies in the current literature that academic self-efficacy is related to various variables such as success orientation (Kayiş, 2013; Solmaz 2014), academic motivation (Alemdağ et al., 2014; Koca \& Dadand, 2019), performance approach orientation (Bell \& Kozlowski, 2002; Cellar et al., 2011), and academic 
motivation (Akbay \& Gizir, 2010; Aydın, 2010). The impact of academic self-efficacy on the success is independent from students' intelligence levels, personality traits and self-esteem (Zuffianò et al., 2013). An individual's academic success is the most decisive factor for their future professional status, income and welfare (Spinath, 2012).

Analyzing teacher candidates' attitudes towards the course of history in different departments of the faculty of education, Altunay-Şam (2007) reported that a vast majority of students was aware of the importance and necessity of history as a course, whereas another group thought that the course was limited to memorizing only specific names and dates and that the courses in this field were taught for memorizing, which made them find history boring and monotonous as a course. It can be inferred from this finding that differences in academic levels of success among students with similar characteristics may occur depending on their academic self-efficacy. In the present study, it is not surprising that there was a relationship between academic self-efficacy and attitudes towards the course of sports history among physical education and sports teacher candidates. The positive attitudes of the students who attend the course of sports history are important in terms of their further success in the course and widening their horizons thanks to the knowledge that they obtain from the course as well as understanding and internalizing the stages which sports have gone through over the years.

In conclusion, a positive relationship was observed between physical education teacher candidates' academic self-efficacy and attitudes towards the course of sports history. It can be thus concluded that this resulted from teacher candidates' academic development during their education as a university student, which is a transition to a professional life, and their belief in the importance of transferring their academic knowledge to the upcoming generations once their professional lives start.

\section{Recommendations}

1) Further studies analyzing the relationship between academic self-efficacy and attitudes towards the course of history for physical education and sports teacher candidates in larger sample groups can be conducted.

2) Taking gender differences into consideration, physical education and sports teacher candidates' attitudes towards the course of history course can be explored.

3) Attitudes of teacher candidates studying in different departments regarding academic self-efficacy and the course of history can be compared.

\section{References}

Abe, I. (1991). Historical studies of sport and physical education in Japan: Recent developments. The International Journal of the History of Sport, 8(2), 291-295. https://doi.org/10.1080/09523369108713761

Akbay S. E., \& Gizir C. A., (2010). Cinsiyete göre üniversite öğrencilerinde akademik erteleme davranış1: Akademik güdülenme, akademik özyeterlik ve akademik yükleme stillerinin rolü. Mersin Üniversitesi Ĕ̈itim Fakültesi Dergisi, 6(1), 60-78.

Alemdağ, C., Öncü, E., \& Yılmaz, A. (2014). Beden Eğitimi Öğretmeni Adaylarının Akademik Motivasyon ve Akademik ÖzYeterlikleri. Hacettepe Spor Bilimleri Dergisi, 25(1), 23-35.

Alp, H., \& Süngü, B. (2016). Üniversite Öğrencilerinin Spora Karşı Tutumlarına Beden Eğitimi ve Spor Dersinin Etkisi. Journal of Research in Education and Teaching, 5(16), 2146-9199.

Altunay-Şam, E. (2007). Amasya eğitim fakültesinde farklı bölümlerde okuyan öğretmen adaylarının tarih dersine ilişkin tutumları. Gazi Ĕgitim Fakültesi Dergisi, 27(3), 1-19.

Aydın, F. (2010). Akademik başarının yordayıcısı olarak akademik güdülenme, öz-yeterlilik ve sinav kaygısl. Yayımlanmamış Yüksek Lisans Tezi. Hacettepe Üniversitesi. Sosyal Bilimler Enstitüsü.

Aydın, S. (2014). Öğretmen Adaylarının Başarı Amaç Yönelimleri ve Akademik Öz-Yeterliklerinin Yapısal Eşitlik Modeliyle İncelenmesi. Turkish Studies-International Periodical for the Languages, Literature and History of Turkish or Turkic, 9(2), 221-230. https://doi.org/10.7827/TurkishStudies.6338

Bell, B. S., \& Kozlowski, W. J. (2002). Goal Orientation and Ability: Interactive Effects on Self-efficacy, Performance, and Knowledge. Journal of Applied Psychology, 87, 497-505. https://doi.org/10.1037/0021-9010.87.3.497

Caba, U., \& Pekel, A. (2017). Üniversite Öğrencilerin Genel Öz Yeterlilik Düzeyleri İle Sporcu Kimlik Algıs1 Arasındaki İlişki (Vakıf Üniversitesi Örneği). The Journal of Academic Social Science, 5(55), 475-482. https://doi.org/10.16992/ASOS.12795

Cellar, D. F., Stuhlmacher, A. F., Young, S. K., Fisher, D. M., Adair, C. K., Haynes, S., ... \& Riester, D. (2011). 
Trait goal orientation, self-regulation, and performance: A meta-analysis. Journal of Business and Psychology, 26(4), 467-483. https://doi.org/10.1007/s10869-010-9201-6

Çıngı, H. (1994). Örnekleme Kuramı. H.Ü. Fen Fakültesi Yayınları, Ankara.

Dalbudak, İ., \& Yiğit, Ş. (2019). Hearing Imparied Students' Attitudes Towards Physical Education and Sports. Journal of Education and Training Studies, 7(9), 55-60. https://doi.org/10.11114/jets.v7i9.4255

Dalbudak, I., Gürkan, A. C., Yigit, S. M., Kargun, M., Hazar, G., \& Dorak, F. (2016). Investigating Visually Disabled Students' Attitudes about Physical Education and Sport. International Journal of Environmental and Science Education, 11(16), 9437-9447.

Demir, E., Saatçioğlu, Ö., \& İmrol, F. (2016). Uluslararası dergilerde yayımlanan eğitim araştırmalarının normallik varsayımları açısından incelenmesi. Current Research in Education, 2(3), 130-148.

Demircioğlu, İ. H. (2014). Türkiye'de tarih eğitimi: sorunlar ve çözüm önerileri. Yeni Türkiye, 59, 1177-1186.

Demirel, Ö., \& Ün, K. (1987). Eğitim Terimleri Sözlüğü. Ankara, Şafak Matbaası.

Dönmez, C. (1998). Atatürk'ün Tarihçi Kişiliği ve Türk Tarihinin Öğretimi ile İlgili Düşünceleri. Gazi Eğitim Fakültesi Dergisi, 18(1).

Donmuş, V., Akpınar, V., \& Eroğlu, M. (2017). Öğretmen Adaylarının Akademik Öz yeterlikleri ve Mesleki Kaygıları Arasındaki İlişkinin İncelenmesi. Mustafa Kemal Üniversitesi Sosyal Bilimler Enstitüsü Dergisi, 14(37), 1-13.

Erden, M. (1998). Öğretmenlik Mesleğine Giriş. İstanbul: Alkım Yayınları.

George, D., \& Mallery, P. (2016). IBM SPSS statistics 23 step by step: A simple guide and reference. Routledge. https://doi.org/10.4324/9781315545899

Gözler, A., \& Taşçi, U. (2015). Sınıf Öğretmenliği Bölüm Öğrencilerinin Bilişim Suçları. International Journal of Informatics Technologies, 8(3), 147-157. https://doi.org/10.17671/btd.11974

Izgar, H., \& Dilmaç, B. (2008). Yöneticiadayi Öğretmenlerin Özyeterlik Algilari Ve Epistemolojik İnançlarinin İncelenmesi. Selçuk Üniversitesi Sosyal Bilimler Enstitüsü Dergisi, 20, 437-446.

Jerusalem, M., \& Schwarzer, R. (1981). Fragebogen zur Erfassung von Selbstwirksamkeit. Skalen zur Befindlichkeit und Persoenlichkeit In R. Schwarzer (Hrsg., Forschungsbericht No. 5). Berlin: Freie Universitaet, Institut fuer Psychologie.

Kan, A., \& Akbaş, A. (2005). Lise öğrencilerinin kimya dersine yönelik tutum ölçeği geliştirme çalışması. Mersin Üniversitesi Eğitim Fakültesi Dergisi, 1(2), 227-237.

Karakuş, M. (2012). Termal Turizm ve Rekreatif Etkinlikler Açısında Kozaklı'nın Değerlendirilmesi. Yayınlanmış Yüksek Lisans Tezi, Sağlık Bilimleri Enstitüsü, Beden Eğitimi ve Spor Anabilim dalı, Kayseri.

Karakuş, M., \& Köse, A. (2018). Ülkemizdeki Yerli Turistlerin Nevşehir-Kozaklı Bölgesindeki Termal Kaplıca Tercihlerindeki Faktörler ile Rekreatif Etkinliklerin Yeterlilik Durumlarının Incelenmesi, Spor Bilimleri Alanında Yenilikçi Yaklaşımlar. Gece kitaplığı (pp. 269-285).

Karasar, N. (2007). Bilimsel Araştırma Yöntemi (17. Baskı). Nobel Yayın Dağıtım Ltd. Şti. Ankara.

Kayiş, A. R. (2013). Üniversite Öğrencilerinin Başarı Yönelimlerinin Incelenmesi. Eskişehir Anadolu Üniversitesi Eğitim Bilimleri Enstitüsü, Yüksek Lisans Tezi, Eskişehir.

Koca, F. (2019). Akademik öz-yeterlik ile akademik başarı arasındaki ilişkide sınav kaygısı ve akademik motivasyonun arac1 rolü. Elementary Education Online, 18(1). https://doi.org/10.17051/ilkonline.2019.527207

Kumartaşl1, M. (2010). İlköğretim ikinci kademe öğrencilerinin beden eğitimi dersine ilişkkin tutumlarının ve yaşam doyum düzeylerinin incelenmesi. Yayınlanmamış doktora tezi, Gazi Üniversitesi, Ankara

Pajares, F. (1996). Self-efficacy beliefs in academic settings. Review of Educational Research, 66(4), 543-578. https://doi.org/10.3102/00346543066004543

Pepe, O., Taskiran, C., Pepe, K., \& Çoksevim, B. (2011). Attitude of first grade teachers of primary education schools related to physical education and sport lessons. Ovidius University Annals, Physical Education and Sport/Science, Movement and Health Series, 11(2), 221-228.

Saracaloğlu, A. S., Aldan-Karademir, Ç. Dursun, F., Altın, M., \& Üstündağ, N. (2017). Sınıf Öğretmeni Adaylarının Öz-Düzenleyici Öğrenme Becerilerinin, Akademik Öz-Yeterlik, Akademik Kontrol Odağı ve 
Akademik Başarıları ile İlişkisi. Turkish Studies International Periodical for The Languages, Literature and History of Turkish Or Turkic, 12(33), 379-402. https://doi.org/10.7827/TurkishStudies.12705

Şeker, S. S. (2017). Müzik Eğitimi Bölümü Öğretmen Adaylarının Akademik Güdülenme ve Akademik Öz-Yeterlik Düzeylerinin İncelenmesi. Abant İzzet Baysal Üniversitesi Eğitim Fakültesi Dergisi, 17(3), 1465-1484. https://doi.org/10.17240/aibuefd.2017.17.31178-338840

Shapiro, L. E. (1999). Yüksek EQ'lu bir çocuk yetiştirme (Çev: Ümran Kartal). İstanbul, Varlık Yayınları.

Spinath, B. (2012). Academic achievement. In V. S. Ramachandran (Ed.), Encyclopedia of human behaviour (pp. 1-9). London: Academic Press. https://doi.org/10.1016/B978-0-12-375000-6.00001-X

Turan, M. B., Karaoğlu, B., Kaynak, K., \& Osman, P. (2016). Özel Yetenek Sinavlarina Giren Adaylarin Genel Öz Yeterlilik Düzeylerinin Bazi Değişkenlere Göre İncelenmesi. Spor Bilimleri Araştırmaları Dergisi, 1(1), 17-26. https://doi.org/10.25307/jssr.274319

Turan, M. B., Usuflu, O., Kenan, K. O. Ç., Karaoğlu, B., \& Ulucan, H. (2018). Profesyonel Futbolcularda Sporda İnsan Hakları Tutumu ve Özgünlük Düzeylerinin İncelenmesi. Gaziantep Üniversitesi Spor Bilimleri Dergisi, 3(4), 1-18. https://doi.org/10.31680/gaunjss.422883

Turkay, H., \& Aydın A. D. (2017). Bir İnceleme: Tarihsel Süreç İçerisinde Türk Spor Örgütlenmesi. Diyalektolog Ulusal Sosyal Bilimler Dergisi, 16, 179-189. https://doi.org/10.22464/diyalektolog.152

Ünlü, H., \& Erbaş, M. K. (2018). Beden Eğitimi Öğretmen Adaylarının Akademik Öz-Yeterlikleri ve Mesleki Kaygıları. Türkiye Spor Bilimleri Dergisi, 2(1), 15-25.

Ünlü, H., \& Kalemoğlu, Y. (2011). Academic self-efficacy of Turkish physical education and sport school students. Journal of Human Kinetics, 27, 190-203. https://doi.org/10.2478/v10078-011-0015-z

Yalçınkaya, M, Saracaloğlu, A., \& Varol, R. (1993). Üniversite öğrencilerinin spora ilişkin görüşleri ve beklentileri. Spor Bilimleri Dergisi, 4(2), 12-26.

Yıldırım, M., \& Bayrak, C. (2019). The participation of university students in physical activities based on sport and the effect of the students' quality of life on academic achievement and socialisation (Sample of Eskisehir Osmangazi University). Hacettepe University Journal of Education, 34(1), 123-144.

Yıldırım, M., Araç-Ilgar, E., \& Uslu, S. (2018). Lise Öğrencilerinin Spora Yönelik Tutumlarının İncelenmesi. Turkish Studies, 13(27), 1711-1727.

Yılmaz, A., Namlı, S., \& Kan A. (2013). Spor Tarihi Dersine Yönelik Tutum Ölçeği Geliştirme Çalışması. IIB International Refereed Academic Social Sciences Journal, 12(4), 49-59.

Yilmaz, M., Gürçay, D., \& Ekici, G. (2007). Akademik Özyeterlik Ölçeğinin Türkçe’ye Uyarlanması. Hacettepe Üniversitesi Ĕ̈itim Fakültesi Dergisi, 33(33), 253-259.

Zuffianò, A., Alessandri, G., Gerbino, M., Kanacri, B. P. L., Di Giunta, L., Milioni, M., \& Caprara, G. V. (2013). Academic achievement: The unique contribution of self-efficacy beliefs in self-regulated learning beyond intelligence, personality traits, and self-esteem. Learning and individual differences, 23, 158-162. https://doi.org/10.1016/j.lindif.2012.07.010

\section{Copyrights}

Copyright for this article is retained by the author(s), with first publication rights granted to the journal.

This is an open-access article distributed under the terms and conditions of the Creative Commons Attribution license (http://creativecommons.org/licenses/by/4.0/). 